\title{
Targeted disruption of the MHC class II Aa gene in C57BL/6 mice
}

\author{
Frank Köntgen ${ }^{1,3}$, Gabriele Süss ${ }^{1,3}$, Colln Stewart ${ }^{2}$, Michael Steinmetz ${ }^{1,4}$, and \\ Horst Bluethmann' \\ 'Department of Biology, Pharmaceutical Research New Technologies, F. Hoffmann-La Roche Ltd, \\ $\mathrm{CH}-4002$ Basel, Switzerland \\ 2Department of Cell and Developmental Biology, Roche Institute of Molecular Biology, Roche Research \\ Center, 340 Kingsland Street, Nutley, NJ 07110, USA \\ 3Present address: The Walter and Eliza Hall Institute of Medical Research, Royal Melbourne Hospital, \\ Parkville, Victoria 3050, Australia \\ ${ }^{4}$ Present address: Preclinical Research, F. Hoffmann-La Roche Inc., Nutley, NJ 07110, USA
}

Key words: C57BL/6 derived embryonic stem cells, targeted mutation by homologous recombination, $\mathrm{MHC}$ class II, thymocyte maturation

\begin{abstract}
The MHC class II gene Aa was disrupted by targeted mutation In embryonic stem (ES) cells derived from C57BL/6 mlce to prevent expression of MHC class II molecules. Contrary to prevlous reports, the effect of the null-mutation on $T$ cell development was Investlgated in C57BL/6 mlce, which provlde a defined genetic background. The complete lack of cell surface expression of $\mathrm{MHC}$ class II molecules in B6-A $0^{\circ} / \mathrm{Aa}^{\circ}$ homozygous mutant mice was directly demonstrated by cytofluorometrlc analysis using antl- $A^{b}$ and antl-la speciflc mAbs. Development of $\mathrm{CD}^{+} \mathrm{CD}^{-} \mathrm{T}$ cells in the thymus was largely absent except for a small populatlon of thymocytes expressing high levels of CD4 together with low amounts of CDB. The majority of these cells express the TCR at high density. Although mature CD4+CD8- T cells were undetectable in the thymus, some T cells with a CD4 + CD8-TCR ${ }^{\text {high }}$ phenotype were found In lymph nodes and spleen. Perlpheral $T$ cells from the mutant mice can be polyclonally activated In vitro with the mitogen concanavalln A. However, they could not be stimulated with staphylococcal enterotoxin $B$ In autologous lymphocyte reactlons, thereby demonstrating the absence of MHC class II expression in these mice. Perlpheral B cells in $\mathrm{B} 6-\mathrm{Aa}^{\mathrm{O}} / \mathrm{Aa}^{\circ}$ mutants were functional and responded to the $T$ cell Independent antigen levan by the production of antigenspecific IgM antibodies similar to wild-type cells. The B6-Aa/Aa mutant mice described in thls study represent an important tool to Investlgate the Involvement of MHC class II molecules in lymphocyte maturation and the Immune response.
\end{abstract}

\section{Introductlon}

Transgenic mouse lines expressing different $\alpha \beta$ TCR have revealed that the specificity of the TCR for either MHC class I or class If molecules directs the development of immature $\mathrm{CD} 4{ }^{+} \mathrm{CD} 8^{+}$thymocytes to either $\mathrm{CD}^{+}{ }^{+} \mathrm{CD} 8^{-}$or $\mathrm{CD} 4-\mathrm{CD} 8^{+}$ mature T cells $(1-5)$. The central role of MHC molecules in the development and function of lymphocytes has also been addressed in MHC class I and MHC class II-deficient mice generated by targeted mutation $(6-9)$. In mice of $\mathrm{H}-2^{\mathrm{b}}$ haplotype, a naturally occurring mutation in the Ea promoter region blocks the expression of Ea genes, and leads to the lack of $E \alpha E \beta$ heterodimers on the surface of thymic epithelial cells, dendritic cells, macrophages, and B cells (10). Cosgrove et al.
(8) and Grusby et al. (9) disrupted the $A b$ gene in $129 / \mathrm{Sv}$ mice and investigated the effect of the inactivation in $129 / \mathrm{Sv} \times$ C57BL 6 hybrids. They found a severe reduction in the development of mature $\mathrm{CD4}{ }^{+} \mathrm{CD} 8-\mathrm{T}$ cells in the thymus of these mice. In the periphery, $\mathrm{CD} 4^{+} \mathrm{CD} 8-\mathrm{T}$ cells accumulated to $\sim 1 / 10$ of the normal amount. Peripheral $T$ cells from mutant mice showed normal proliferative responses to the mitogen concanavalin A (Con A). In addition, mutant mice mounted a normal antigen-specific $\lg M$ response to haptenated ovalbumin, but were unable to switch to lgG isotypes (9). The lg isotype profile after immunization with the $\mathrm{T}$ cell independent antigen levan, however, was normal (8). 
The MHC class II deficient mice generated thus far could potentially express $A \alpha E \beta$ heterodimers which may select $C D 4^{+}$ T cells. To exlcude the possible surface expression of $A \alpha E \beta$ heterodimers of mixed isotypes, we introduced a null-mutation in the $A a$, rather than in the $A b$ gene. We report here the first targeted mutation in C57BL 6 mice by homologous recombination in embryonic stem (ES) cells derived from this strain. Germ line competence of another ES cell line derived from C57BL/6 was recently demonstrated, but no gene targeting has been reported yet (11). C57BL/6 mice are immunologically well characterized, and a large variety of mutations affecting the immune system are known in this strain. MHC class II deficient $\mathrm{B} 6-\mathrm{Aa}^{0} / \mathrm{Aa}^{\mathrm{O}}$ mice will facilitate investigation of the various roles of MHC class II molecules in lymphocyte maturation, T - B cell interaction, and antigen presentation in the normal and diseased state.

Here we show that $\mathrm{T}$ cell development in $\mathrm{B} 6-A a^{0} / A a^{0}$ mice is severely impaired. No mature $\mathrm{CD} 4{ }^{+} \mathrm{CD} 8-\mathrm{T}$ cells were detectable in the mutant thymus, whereas $\mathrm{CD4}+\mathrm{CD} 8^{\text {low }}$ cells appeared at normal frequencies even in the absence of $\mathrm{MHC}$ class II expression. Peripheral T cells responded normally to the mitogen Con A. They were, however, largely unresponsive to the staphylococcal enterotoxin B (SEB) superantigen using autologous splenocytes as presenting cells, which demonstrates the absence of classical MHC class II expression in these mice.

\section{Methods}

Construction of the targeting vector

The cosmid clone $A B 19$ containing the $A a^{b}$ allele was obtained from E. Weiss (University of Munich, Germany). The replacement vector for gene targeting was constructed from a $4.0 \mathrm{~kb}$ $B a m H I-X b a l$ fragment by insertion of a PGKneo poly $(A)^{+}$ cassette $(12,13)$ into the Hindlll site of the second exon encoding the $\alpha 1$ domain of the A $\alpha$ chain (Fig. 1). This disrupts the coding sequence of the gene and creates a null-mutation. The HSV-tk gene used for negative selection was added $5^{\prime}$ to the fragment.

\section{Gene targeting in C57BL/6 embryonic stem cells}

ES cells were derived from mouse strain C57BL/6-Thy1.1 (14). They were grown on 3000 rad irradiated primary embryonic feeder cells derived from strain CD1-MTKneo2 transgenic for the neomycin resistance gene (15) and $100 \mathrm{U} / \mathrm{ml}$ LIF. The culture medium was based on Dulbecco's minimal essential medium supplemented with $15 \%$ FCS, 2 mM glutamine, $1 \times$ non-essential amino acids, $0.1 \mathrm{mM} \beta$-mercaptoethanol, and $100 \mathrm{U} / \mathrm{ml}$ penicillin - streptomycin. The targeting vector was linearized by Clal digestion. Approximately $5 \times 10^{7}$ ES cells were transfected by electroporation at $250 \mathrm{~V} / 500 \mu \mathrm{F}$ in a BioRad gene pulser and plated on five $6 \mathrm{~cm}$ gelatinized dishes containing neomycin resistant embryonic feeder cells. Transfectants were positively selected with $350 \mu \mathrm{g} / \mathrm{ml}$ Geneticin (G418 Gibco, Paisley, UK) starting at day 1 after electroporation and negatively with $0.2 \mu \mathrm{M}$ FIAU (Oclassen, San Rafael, CA) after 3 days in culture. Resistant clones were picked and expanded in 48-well plates (16). Homologous recombinants were identified by polymerase chain reaction (PCR) analysis using the following primers: $5^{\prime}$-ATA TTG CTG AAG AGC TTG GCG GC-3' as 5' primer complementary to a sequence of the neomycin resistance gene and $5^{\prime}$-CAC AGT CTC TGT CAG CTC TGT GAC-3' as 3' primer specific for exon 4 of the Aa gene. This leads to the amplification of a $1.8 \mathrm{~kb}$ fragment from the mutant allele after correct targeting.

PCR amplifications were carried out in a buffer containing $8.3 \mathrm{mM}\left(\mathrm{NH}_{4}\right)_{2} \mathrm{SO}_{4}, 25 \mathrm{mM} \mathrm{KCl}, 40 \mathrm{mM}$ Tris $-\mathrm{HCl}, \mathrm{pH} 8.8$, $1.5 \mathrm{mM} \mathrm{MgCl} 2,0.2 \%$ Nonidet-P40, $0.2 \%$ Tween 20 , $0.05 \mathrm{mg} / \mathrm{ml}$ BSA, $0.1 \mathrm{mM}$ dNTPs, and $0.5 \mu \mathrm{M}$ primers each. Forty cycles were used for amplification with the following parameters: denaturation at $95^{\circ} \mathrm{C}$ for $20 \mathrm{~s}$, annealing at $65^{\circ} \mathrm{C}$ for $30 \mathrm{~s}$, and extension at $72^{\circ} \mathrm{C}$ for $1 \mathrm{~min}$. Targeted mutation was verified by Southern blot analysis of BamHI digested DNA using a $600 \mathrm{bp}$ $X b a l-E c o R l$ fragment covering exons 4 and 5 as a probe (not

\section{(A)}

(B)
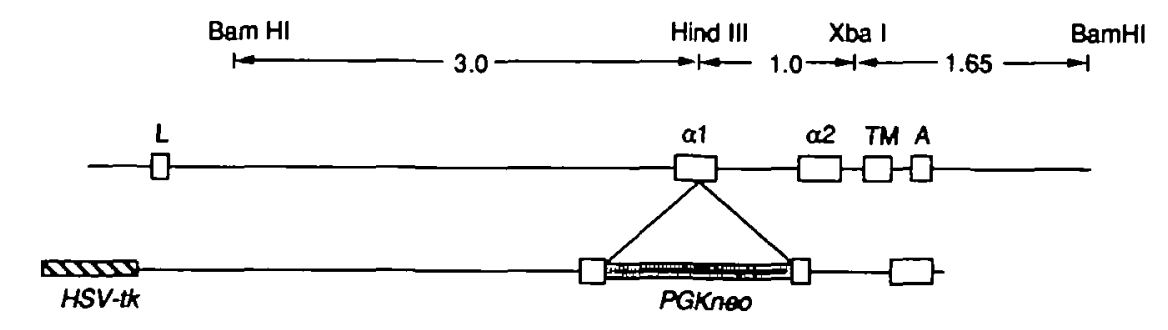

(C)

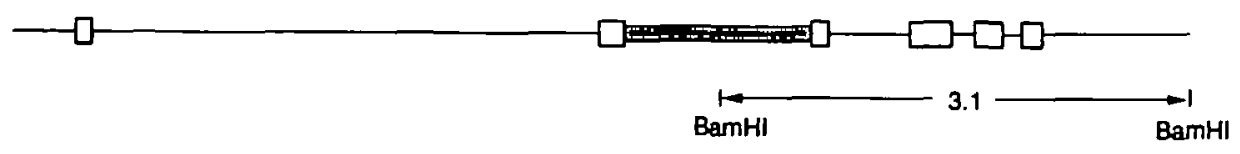

Flg. 1. Targeted mutation of the $A a^{b}$ gene in C57BL/6 derived ES cells. (A) Genomic structure of the Aab gene. (B) The targeting vector was generated from a $B a m H I$ - Xbal fragment of the $A a^{b}$ gene by introducing a $P G K n \theta 0$ pol(A) ${ }^{+}$cassette into a unique $H$ indll site in exon 2 . The $H S V$ - $t k$ gene was added $5^{\prime}$ to the vector. The vector contained $3 \mathrm{~kb}$ homology on the $5^{\prime}$ site and $1 \mathrm{~kb}$ homology on the $3^{\prime}$ site. (C) Mutant Aa allele after homologous recombination. 
shown). Homologous integration occurred in two out of 480 clones screened. One of these clones, Bruce 4.1, was used for further experiments.

Generation of germ line chimeras and homozygous mutant offspring

Microinjection of ES cells into blastocysts was performed essentially as described (17). Blastocysts were collected from BALB/c females at day 4 of pregnancy in CZB medium (18). ES cell cultures were trypsinized and transferred to gelatinized $6 \mathrm{~cm}$ dishes. Feeder cells were allowed to attach to the culture dish for $1 \mathrm{~h}$ and then loosely adherent ES cells were removed by gentle pipetting. About $15 \mathrm{ES}$ cells were injected per blastocyst. Mutant stem cells from clone Bruce 4.1 were injected into 283 blastocysts, which were reimplanted into B6CBAF1 foster mothers. Fifty-two offspring were born, 23 of which were chimeric as revealed by their mosaic coat colour. Ten chimeric males were bred with C57BL 6 females and five transmitted the mutation to the offspring as determined by PCR and Southern blot analysis (not shown). Digestion of DNA with BamHI and subsequent hybridization of the blot with a $600 \mathrm{bp} \mathrm{Xbal} \mathrm{-} \mathrm{EcoRI} \mathrm{probe} \mathrm{specific}$ for exons 4 and 5 revealed a $3.1 \mathrm{~kb}$ band indicative of the mutant allele, in addition to the $5.5 \mathrm{~kb}$ band derived from the wild-type allele. Heterozygous mutant offspring (B6-Aa\%+) were interbred to establish the new strain $B 6-A a^{0} / A a^{\circ}$ homozygous for the nullmutation in the Aa gene.

\section{Cytofluorometric analysis}

Lymphocytes were analysed after fluorescent labelling with a FACScan flow cytometer (Becton-Dickinson, Mountain View, CA) as described previously (19). Briefly, thymus and lymph nodes homogenized, and the cells were recovered and washed twice in PBS, $4 \%$ FCS, $0.1 \% \mathrm{NaN}_{3}$ at $4^{\circ} \mathrm{C}$. About $5 \times 10^{5}$ cells per sample were stained in the same buffer with optimal concentrations of antibodies. The following antibodies were used: antimouse CD4-phycoerythrin (Becton-Dickinson), anti-mouse CD8 - FITC (Becton-Dickinson), anti-mouse CD3 - - biotin, antimouse $\alpha \beta T C R$ - biotin, anti-mouse heat stable antigen (HSA) biotin, anti-mouse Pgp-1-biotin, anti-mouse $1-A^{b}$ - biotin (AF6-120.1), anti-mouse la lakb.qssis - biotin (7-16.17), anti I-Edk.ps biotin (AMS-16), all from PharMingen, San Diego, CA; anti-mouse TCR $V_{\beta} 2(B 20.6 .5,(20))$, anti-mouse TCR $V_{\beta} 3(\mathrm{KJ} 25 \mathrm{a}$, (21)), anti-mouse TCR $V_{\beta} 4$ (KT4-3, K. Tomonari, Medical Research Council, Harrow, UK), anti-mouse TCR $V_{\beta} 6$ (44-22-1, (22)), antimouse TCR $V_{\beta} 8$ (F23.1, (23)), anti-mouse TCR $V_{\beta} 11$ (KT11, (24)), anti-mouse TCR $V_{\beta} 12$ (MR11, O. Kanagawa, Washington University, St Louis, MO), anti-mouse TCR $\mathrm{V}_{\beta} 17 \mathrm{~A}(\mathrm{KJ} 23 \mathrm{a},(25))$.
Secondary reagents were FITC-labelled anti-mouse $\mathrm{lg}$, and FITClabelled anti-rat Ig (Silenus Laboratories, Victoria, Australia) or Streptavidin-Cy-Chrome (PharMingen).

In vitro stimulation of splenocytes

Purified spleen cells $\left(4 \times 10^{5}\right.$ cells/well) were stimulated with either $5 \mu \mathrm{g} / \mathrm{ml}$ Con A, $10 \mu \mathrm{g} / \mathrm{ml} \mathrm{SEB}$, or $50 \mu \mathrm{g} / \mathrm{ml}$ lipopolysaccharide (LPS) (all from Sigma, St Louis, MO) for three, four and five days. Addition of $1 \mu \mathrm{Ci}$ of $\left[{ }^{3} \mathrm{H}\right]$ thymidine (Amersham, Arlington Heights, IL) to each well was done $12 \mathrm{~h}$ or more before harvesting and $\left[{ }^{3} \mathrm{H}\right]$-thymidine uptake was measured by liquid scintillation counting.

\section{$T$ cell independent immune responses}

$\mathrm{B} 6-\mathrm{Aa} / \mathrm{Aa}^{0}$ mutant mice and age and sex matched $\mathrm{C} 57 \mathrm{BL} / 6$ control mice were immunized by intraperitoneal injection of $100 \mu \mathrm{g}$ levan dissolved in $100 \mu \mathrm{l}$ PBS (Sigma). Mice were bled at day 5 and day 10 by retro-orbital puncture and $\lg M$ titres in the serum determined by ELISA. For this assay microtiter plates were coated overnight at $4^{\circ} \mathrm{C}$ with $20 \mu \mathrm{g} / \mathrm{ml}$ levan in PBS. After two washing steps with PBS, $0.1 \%$ Tween 20 , wells were blocked for $2 \mathrm{~h}$ with $1 \%$ BSA, $0.1 \%$ Tween 20 in PBS, washed again, and incubated with serial dilutions of serum samples in PBS, 1\% BSA, $0.1 \%$ Tween 20 for $2 \mathrm{~h}$. Wells were washed five times, incubated with $100 \mu \mathrm{l}(500 \mathrm{ng}$ ) goat anti-mouse affinity-purified anti- $\mu$ chain Ig fraction conjugated to alkaline phosphatase in PBS, 1\% BSA for $1 \mathrm{~h}$ and washed again. Enzymatic reaction was started by addition of $200 \mu 0.4 \mathrm{mg} / \mathrm{ml}$ paranitrophenylphosphate in diethanolamine buffer, $\mathrm{pH} \mathrm{9.8,} \mathrm{and} \mathrm{the} \mathrm{optical} \mathrm{density} \mathrm{was}$ measured at $405 \mathrm{~nm}$.

\section{Results}

MHC class /I molecules are not expressed in $B 6-A a^{\circ} / A a^{\circ}$ mice as revealed by FACS analysis

In $B 6-A a^{0} / A a^{\circ}$ mutant mice, thymi and lymph nodes were normal or somewhat enlarged and contained slightly higher numbers of thymocytes and lymphocytes respectively (Table 1).

To investigate $\mathrm{MHC}$ class II expression in normal C57BL/6 and mutant $B 6-A a^{0} / A a^{0}$ mice, $B$ lymphocytes were stained with antibodies specific for $A \alpha A \beta$ and $E \alpha E \beta$ heterodimers and analysed by flow cytometry. As expected, B cells from normal C57BL/6 mice, which carry a defective Ea gene, could be stained only with anti-A $\mathrm{A}^{\mathrm{b}}$ and anti-la antibodies (Fig. 2), but not with anti-E antibodies (not shown). B cells from homozygous mutants, however, gave only background staining with any of these anti-

Table 1. Number of cells in lymphatic organs

\begin{tabular}{|c|c|c|c|c|}
\hline \multirow[t]{2}{*}{ Organ } & \multirow[t]{2}{*}{$A B$} & \multicolumn{3}{|l|}{ Mice analysed } \\
\hline & & 5 week, female & 7 week, male & 8 week, female \\
\hline $\begin{array}{l}\text { Thymus } \\
\text { Lymph node }\end{array}$ & $\begin{array}{l}\text { wild-type } \\
A a^{0} / A a^{0} \\
\text { wild-type } \\
A a^{0} / A a^{0}\end{array}$ & $\begin{array}{r}150 \times 10^{6} \\
190 \times 10^{6} \\
16 \times 10^{6} \\
36 \times 10^{8}\end{array}$ & $\begin{array}{r}150 \times 10^{8} \\
170 \times 10^{6} \\
25 \times 10^{6} \\
31 \times 10^{8}\end{array}$ & $\begin{array}{r}98 \times 10^{8} \\
179 \times 10^{6} \\
15 \times 10^{6} \\
26 \times 10^{6}\end{array}$ \\
\hline
\end{tabular}

Thymocytes and cells from lymph nodes (mesenteric, axillary, and inguinal) were counted in wild-type C57BL6 and $B 6-A a^{\circ} / A a^{0}$ homozygous mutant mice at different ages. The sex of the mice is indicated. 
$1-A^{b}$
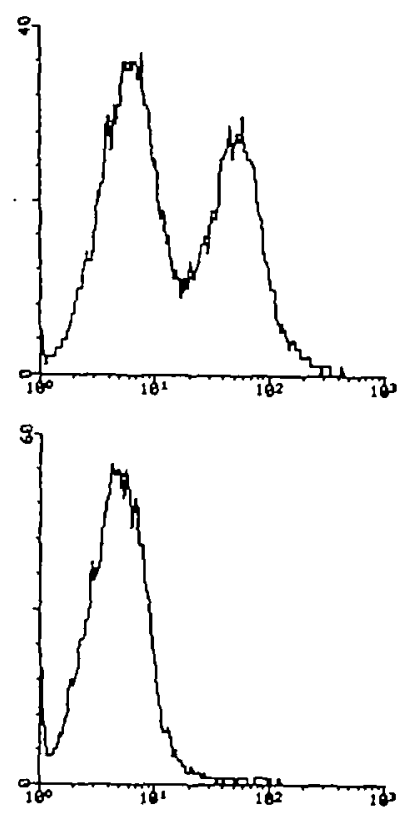

la
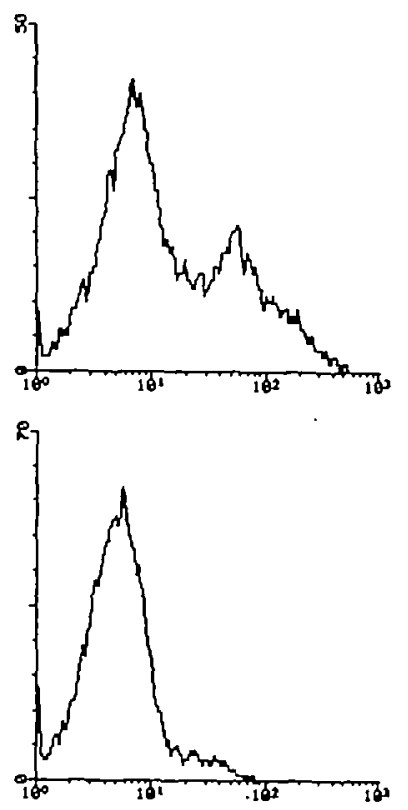

C57BL/6

B6. $A a^{O} / A a^{0}$

Fig. 2. Cytofluorometric analysis of B lymphocytes for surface expression of MHC class II molecules. B cells from C57BL6 mice wild-type and $B 6-A a^{0} / A a^{0}$ homozygous mutants were stained with mAbs AF6-120.1 and 7-16.17 specific for $1-A^{b}$ and la molecules respectively. No surface expression of $A \alpha A B$ was detected on $B$ cells from $B 6-A a^{0} / A a^{\circ}$ mutants.

bodies. This shows that disruption of the Aa gene indeed blocked the expression of $A \alpha A \beta$ heterodimers in these mice. The virtually complete absence of MHC class II expression in B6-Aa\% $/ A a^{0}$ mutants was confirmed by a functional assay using SEB (see below).

\section{Phenotype of thymacytes}

The consequences of $\mathrm{MHC}$ II deficiency in $\mathrm{B} 6-A a^{\circ} / A a^{\circ}$ mutant mice for the development of thymocytes were analysed using mAbs specific for different developmentally regulated surface molecules. Virtually no CD4 $+\mathrm{CD8} 8-\mathrm{T}$ cells could be detected in the mutant thymus as opposed to $\sim 3 \%$ in the control (Fig. 3a). However, a $\mathrm{CD} 4{ }^{+} \mathrm{CD} 8^{\text {low }}$ population could be discerned, which comprised about $2 \%$ of the total number of thymocytes, comparable to wild-type mice. $\mathrm{CD}^{+}{ }^{+} \mathrm{CD} 8^{+}, \mathrm{CD}^{-}{ }^{-} \mathrm{CD} 8^{+}$, and $\mathrm{CD} 4^{-} \mathrm{CD}^{-}$thymocytes occur at normal frequencies in $\mathrm{B6}-\mathrm{Aa} / \mathrm{Aa^{0 }}$ mice. In mutant mice, the $\mathrm{CD} 4^{+} \mathrm{CD} 8^{+}$cells show a 1.7-fold higher surface expression of CD4 compared with normal thymocytes (not shown). A similar increase was found in the $\mathrm{CD}^{+}{ }^{+} \mathrm{CD} 8^{\text {low }}$ population of the mutant. Surface expression of CD8 in these cells is only slightly increased.

The number of TCR ${ }^{\text {ngh }}$ expressing cells is normally low, i.e. $\sim 8 \%$ in normal mice and reduced slightly to $\sim 6 \%$ in mutant mice (Fig. 3b). However, the distribution of $\mathrm{TCR}^{\text {hboh }}$ expressing cells in thymocyte subpopulations was changed in class II deficient mice. There was an increase of TCR high cells from 1.9 to 396 in the $\mathrm{CD}^{+}{ }^{+} \mathrm{CD} 8^{+}$population (Fig. $3 \mathrm{C}$ ). $\mathrm{CD} 4{ }^{+} \mathrm{CD} 8$ low cells in both normal and mutant mice were mostly $\mathrm{TCR}^{\text {hioh }}$ expressing thymocytes. Expression of the Pgp-1 antigen on the cell surface of thymocytes changes during development and was found to be highest on medullary thymocytes (26). Cytofluorometric analysis revealed that $\mathrm{Pgp}-1^{\text {high }}$ expressing cells were diminished by a factor of $\sim 2$ in $B 6-A a^{\circ} / A a^{0}$ mutants (not shown). The expression level of another developmentally regulated surface molecule on thymocytes, the HSA, was not influenced by the $A a^{0}$ mutation.

\section{Phenotypes of lymphocytes}

As in the thymus, the composition of $T$ cell subpopulations in peripheral fymphatic organs of $\mathrm{B} 6 \cdot \mathrm{Aa} / \mathrm{Aa} \mathrm{a}^{0}$ mutant mice was drastically different from normal mice. Only $\sim 4 \% \mathrm{CD} 4^{+} \mathrm{CD} 8^{-}$ $T$ cells could be detected in the lymph nodes of mutant mice compared with $-60 \%$ in control mice. This strong reduction was accompanied by an increase in both relative and absolute numbers of $\mathrm{CD4}-\mathrm{CDB}^{+} \mathrm{T}$ cells (Fig. 4). Lymph node $\mathrm{T}$ cells from mutant mice consist almost entirely ( $-90 \%$ ) of CD8 single positive cells. The expression level of both CD4 and CD8 molecules appeared to be normal. The remaining $\mathrm{CD} 4{ }^{+} \mathrm{CD} 8-$ $T$ cells in mutant mice were polyclonal in origin and expressed an apparently normal TCR $V_{\beta}$ repertoire (Table 2).

\section{Functional analysis of splenocytes}

Functionality of splenocytes from $B 6-A a^{0} / A a^{0}$ mice was investigated by proliferation assays. With the $T$ cell mitogen Con A, variable responses were induced; however, these did not differ significantly from control experiments (not shown). The superantigen SEB caused strong proliferation of wild-type splenocytes, while mutant $T$ cells practically did not respond in several independent autologous mixed lymphocyte reactions. Proliferation was found to be 25 times lower compared with the control and reached only about twice the background level obtained with medium alone (Fig. 5a). This almost complete 
a

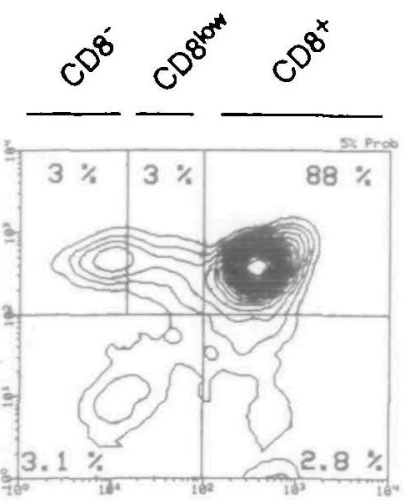

C57BL/6

CD4

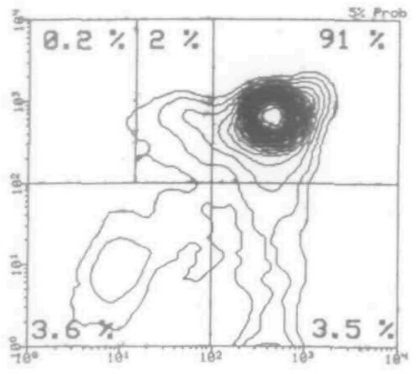

b

B6. $A a^{O} / A a^{O}$

\section{$\alpha \beta T C R$}

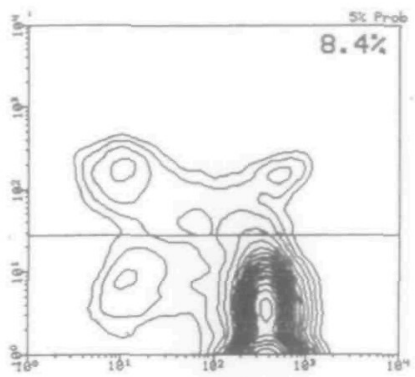

C57BL/6

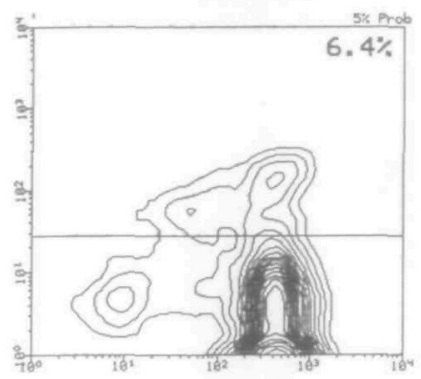

B6. $A a^{O} / A a^{O}$

CD8

c

TCR high

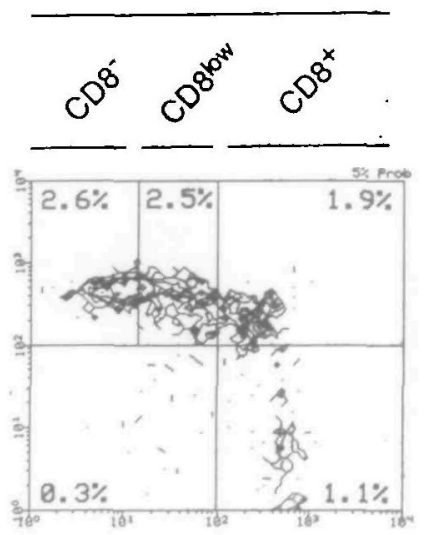

\section{C57BL/6}

\section{CD8}

CD4

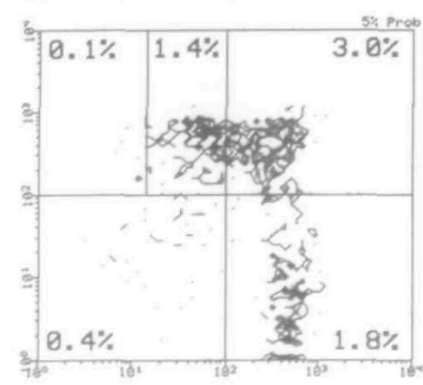

B6. $A a^{O} / A a^{O}$

\section{CD8}

Fig. 3. Phenotype of thymocytes. (A) Thymocytes from C57BL/6 wild-type mice and B6-A $a^{0} / A a^{\circ}$ homozygous mutants were stained with anti-CD4 anti-CD8, and anti- $\alpha$ BTCR mAbs and analysed by three-colour cytofluorometry. Relative sizes of subpopulations are given as percentages in the quadrants of the contour plots. Three CD4 expressing populations can be discriminated, $\mathrm{CD4} 4^{+} \mathrm{CD} 8^{+}, \mathrm{CD} 4^{+} \mathrm{CD} 8^{\circ{ }^{\prime}}$, and $\mathrm{CD} 4^{+} \mathrm{CD} 8^{-}$cells. B6- $A s^{\circ} / A g^{0}$ mutants were deffient in $\mathrm{CD} 4^{+} \mathrm{CD} 8^{-}$thymocytes, but contained $\mathrm{CD} 4^{+} \mathrm{CD} 8^{\text {low }}$ cells. (B) Expression of $\alpha \beta$ TCR on thymocytes from wild-type mice and $B 6-A \theta^{\circ} / A A^{0}$ mutarts. Numbers give the percentege of TCR hish expressing thymocytes. (C) Distribution of thymocytes expressing $i \quad$ : high levels of TCR are shown in the contour piot. Numbers in the quadrants give refive percentages of TCR high cells in thymocyte subpopulations. $\therefore$

$\therefore$ 
unresponsiveness to SEB of spleen cells from mutant mice is expected based on the deficiency of classical MHC class II expression in them. The bacterial toxin LPS, a B cell mitogen, had the same effect on mutant as on normal splenocytes.

\section{Immunization with $T$ cell independent antigen}

Protein antigens must be presented as peptide fragments by $\mathrm{MHC}$ class II molecules on antigen presenting cells in order to elicit an immune response. T cell independent antigens, however, normally polymeric molecules with repeated epitopes, stimulate $B$ lymphocytes directly by cross-linking their Ig receptors. When mutant mice were immunized with the $T$ cell independent anti-

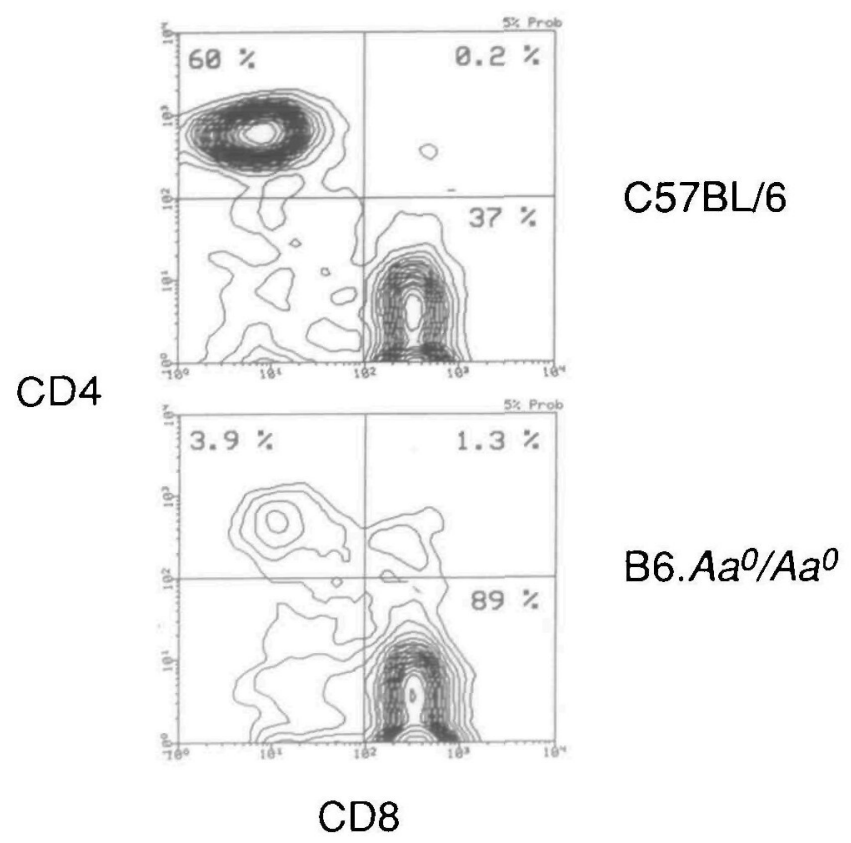

Flg. 4. Cytofluorometric analysis of peripheral $\alpha \beta$ TCR T cells. Lymph node cells from wild-type mice and $\mathrm{B} 6-A a^{\circ} / A a^{\circ}$ mutants were stained with anti-CD4, anti-CD8, and anti- $\alpha \beta T C R$ antibodies and analysed by three-colour cytofluorometry. Contour plots from $\alpha \beta \mathrm{TCR}^{+} \mathrm{T}$ cells are shown. Numbers in quadrants give relative percentages of subpopulations. Frequency of $\mathrm{CD4}^{+} \mathrm{CD} 8^{-} \mathrm{T}$ cells were reduced from 60 to $4 \%$ in mutant mice, whereas $\mathrm{CD}^{-}{ }^{-} \mathrm{CD} 8^{+} \mathrm{T}$ celts were increased from 37 to $89 \%$. gen levan, they responded with a normal increase in antigenspecific $\lg M$ titers (Fig. 5b).

\section{Dlscussion}

MHC class II molecules are expressed as $A \alpha A \beta$ and $E \alpha E \beta$ heterodimers on the cell surface of thymic epithelial cells, dendritic cells, macrophages, and B cells in the mouse. Heterodimers of mixed isotypes were identified in vivo only for the d-haplotype. Ruberti et al. (27) found that $A \beta^{d} E \alpha^{d}$ heterodimers played a major role in the immune response of normal mice towards a peptide from sperm whale myoglobin. In in vitro transfection experiments, formation of $A \beta E \alpha$ heterodimers, but not the reciprocal $\mathrm{A} \alpha \mathrm{E} \beta$ complexes, has been observed in several laboratories $(28-31)$. To generate a mouse strain with no expression of classical MHC class II molecules, lacking even the hypothetical heterodimers of mixed isotypes, we chose to inactivate the $A a$ gene, rather than the $A b$ gene, in mice of $\mathrm{H} \cdot 2^{b}$ haplotype. Absence of $\mathrm{A} \alpha \mathrm{A} B$ expression in $\mathrm{B} 6-\mathrm{Aa} / \mathrm{Aa^{0 }}$ mutant mice was demonstrated by cytofluorometry with two different mAbs. This result was confirmed by a highly sensitive analysis of $\mathrm{MHC}$ class II expression using the superantigen SEB in a functional assay. SEB is a very potent stimulator of $T$ cells based on its ability to cross-link MHC class II molecules with certain $V_{\beta}$ elements. $T$ cells from $B 6-A a^{0} / A a^{0}$ mutant mice were almost completely unresponsive to stimulation with SEB using autologous splenocytes as presenting cells, but did respond to the mitogen Con $A$, which induces proliferation by direct binding to mitogen receptors on $T$ cells. The very low remaining inducibility by SEB may indicate the presence of other $\mathrm{MHC}$ class II-like molecules (37).

The central role of MHC class II molecules for the development of $\mathrm{CD} 4{ }^{+} \mathrm{CD} 8-\mathrm{T}$ cells has been confirmed in experiments with transgenic $(4,5)$ and knock-out mouse strains $(8,9)$. We have also found an up-regulation of $\mathrm{CD} 4$ expression in $\mathrm{CD} 4{ }^{+} \mathrm{CD} 8+$ thymocytes in mutant mice, as observed previously by Cosgrove et al. (8). The avidity of thymocyte interaction with $\mathrm{MHC}$ molecules on stromal cells during maturation is determined by contributions from both the $\alpha \beta$ TCR and the coreceptor molecules. Lack of TCR - MHC class II interaction in $B 6-A a^{\circ} / A a^{\circ}$ mutants may lead to an up-regulation of $\mathrm{CD} 4$ expression on thymocytes to compensate for this deficiency. Alternatively, TCR-MHC class II interaction may be needed to limit $\mathrm{CD} 4$ expression in $\mathrm{CD} 4^{+} \mathrm{CD} 8^{+}$thymocytes. This explanation is supported by the

Table 2. TCR $V_{\beta}$ expression in $T$ lymphocytes

\begin{tabular}{|c|c|c|c|c|}
\hline \multirow[t]{2}{*}{$V_{\beta}$ region } & \multicolumn{2}{|c|}{$\mathrm{CD}_{4}+\mathrm{T}$ cells } & \multicolumn{2}{|c|}{$\mathrm{CDB}^{+} \mathrm{T}$ cells } \\
\hline & $A a^{0} / A a^{0}$ & wild-type & $A a^{\circ} / A a^{0}$ & wild-type \\
\hline $\begin{array}{r}2 \\
3 \\
6 \\
8 \\
4,11,12 \\
17 \mathrm{~A}\end{array}$ & $\begin{array}{r}3.5 \% \\
5.7 \% \\
5.9 \% \\
32.9 \% \\
6.7 \% \\
1.0 \%\end{array}$ & $\begin{array}{r}6.2 \% \\
6.1 \% \\
7.4 \% \\
23.2 \% \\
9.8 \% \\
0.5 \%\end{array}$ & $\begin{array}{r}5.1 \% 6 \\
4.8 \% \\
8.2 \% \\
22.9 \% \\
10.6 \% \\
1.3 \%\end{array}$ & $\begin{array}{r}4.8 \% \\
4.6 \% \\
7.8 \% \\
26.2 \% \\
11.4 \% \\
2.0 \%\end{array}$ \\
\hline
\end{tabular}

Numbers give percentages of $\mathrm{T}$ cells in the $\mathrm{CD}^{+}$or $\mathrm{CD}^{+}$population expressing the indicated $\mathrm{V}_{\theta} \mathrm{TCR}$ region. Data were obtained by three-colour cytofluorometric analysis with anti-CD4, anti-CD8, and different anti- $V_{\beta}$ antibodies. $V a l u e s$ for $V_{\beta} 4, V_{\beta} 11$, and $V_{\beta} 12$ expressing $T$ cels were summarized. No significant difference between mutant and control mice in $V_{\beta}$ expression by CD4 $+{ }^{+} T$ cefls was identified. 
recent identification of a TCR-induced post-transcriptional regulation of the level of CD4 and CD8 messenger RNAs in early thymocytes (32).

We have detected a relative increase in the number of $\alpha \beta$ $\mathrm{TCR}^{\text {hat }}$ expressing $\mathrm{CD} 4{ }^{+} \mathrm{CD} 8+$ thymocytes in mutant mice, but no increase in their level of TCR expression, contrary to what was reported in $A b^{\circ} / A b^{0}$ mutant mice by Cosgrove et al. (8). In vivo experiments using anti-MHC class II antibodies also showed no up-regulation of TCR levels on thymocytes $(33,34)$.

We have identified a distinct population of CD4 $4^{\text {hion }} C D 8^{\text {bow }}$ cells accumulating in the thymus of $B 6-A a^{\circ} / A a^{\circ}$ mice in the absence of MHC class II expression. Most of these cells express the $\alpha \beta$
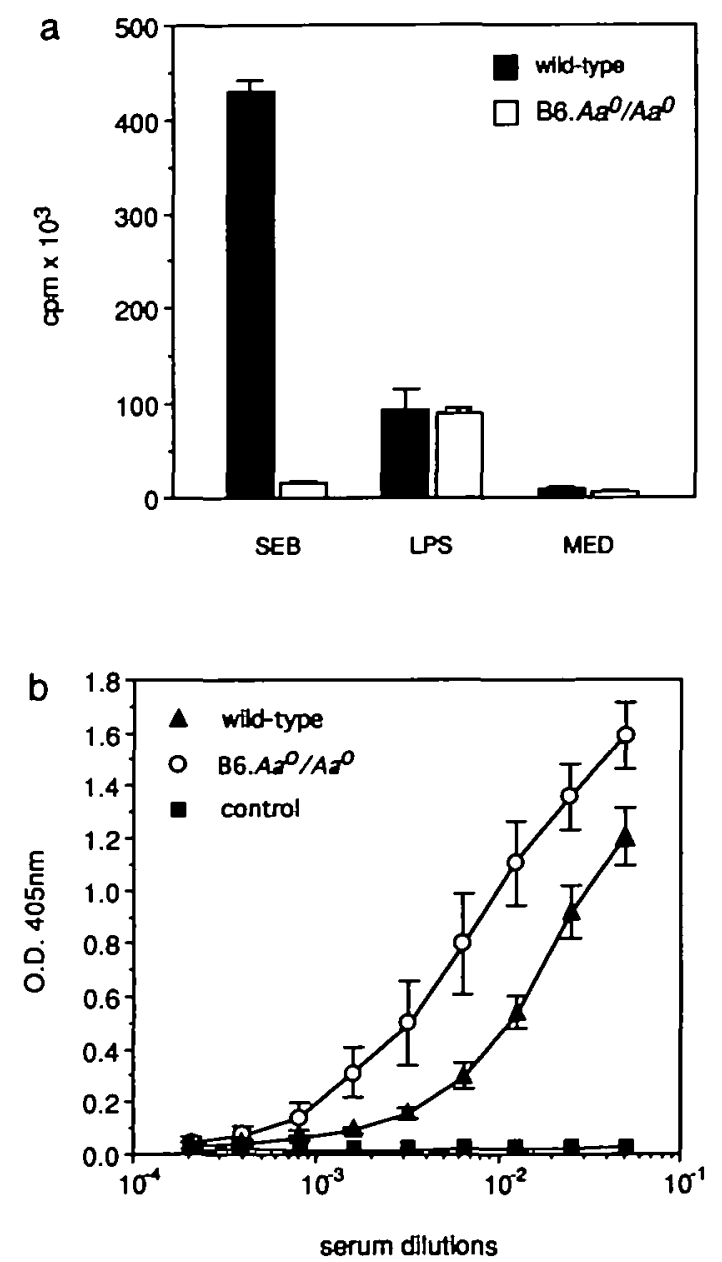

Fig. 5. (A) Proliferative responses of splenocytes. Splenocytes from wildtype mice (black bars) and $B 6-A a^{0} / A a^{\circ}$ mutants (open bars) were stimulated in vitro with the superantigen SEB or the mitogen LPS, and $\left[{ }^{3} \mathrm{H}\right]$ thymidine incorporation measured after 3 days in culture. Values are given as mean of three measurements $\pm S D$. Incorporation by unstimulated splenocytes is shown for controt (MED). There was a greatty diminished proliferative response to SEB by cells from mutant mice, whereas LPS induced proliferation in cells from both wild-type and mutant mice. (B) Antigen-specific serum IgM titers after immunization with the $T$ cell independent antigen levan. Wild-type C57BL/6 and $B 6-A a^{0} / A a^{\circ}$ mutant mice were immunized by intraperitoneal injection of levan and serum analysed after 10 days by an ELISA for antigen-specific lgM titers. Values are mean of four (wild-type) or three (mutant) measurements $\pm S D$. Mutant mice respond to levan similarty as control mice.
TCR at high levels, as in normal mice. It has been proposed that $\mathrm{CD} 4{ }^{+} \mathrm{CD} 8^{\text {low }}$ or $\mathrm{CD} 4^{\text {low }} \mathrm{CD} 8^{+}$thymocytes represent an intermediate stage of thymocyte development following positive selection of immature $\mathrm{CD} 4{ }^{+} \mathrm{CD} 8^{+}$cells $(35,36)$. In our $\mathrm{MHC}$ class II deficient $B 6-A a^{\circ} / A a^{0}$ mice, positive selection of $\mathrm{CD}^{+}{ }^{+} \mathrm{CD} 8^{\text {low }} \mathrm{TCR}^{+}$transitional cells by classical MHC class II molecules can be excluded. However, it is possible that they may have been positively selected by the novel MHC class II molecule $\mathrm{H}-20$ (37). In this case, further maturation by interaction with $\mathrm{H}-20$ molecules seems to be extremely inefficient, since mature $\mathrm{CD} 4{ }^{+} \mathrm{CD} 8^{-}$thymocytes are virtually undetectable in our mutant mice. It is possible that thymocyte development to the $\mathrm{CD} 4{ }^{+} \mathrm{CD}^{\text {low }}$ stage occurs stochastically in the absence of TCR-MHC interaction, but that in subsequent stages of development, complete down-regulation of CD8 in these cells requires interaction with $\mathrm{MHC}$ class II molecules. It may also be that $\mathrm{CD} 4^{+} \mathrm{CD} 8^{\text {bow }} \mathrm{T}$ cells from the mutant had matured by interaction of their TCR with MHC class | instead of class II molecules. If $\mathrm{CD}^{+}{ }^{+} \mathrm{CD} 8^{+}$thymocytes expressed a TCR with sulficiently high affinity for $\mathrm{MHC}$ class I molecules to be independent of the contribution by the coreceptor molecule, $T$ cells with an inappropriate TCR - co-receptor combination may develop, e.g. CD4 expressing but class I restricted thymocytes. Finally, CD4 ${ }^{+} \mathrm{CD} 8^{\text {bw }}$ cells may represent apoptotic cells that have failed to be positively selected in the mutant mouse.

Although $\mathrm{CD} 4{ }^{+} \mathrm{CD} 8$ - were undetectable in the thymus of $B 6-A a^{0} / A a^{0}$ mice, they appear at low frequency in the periphery. These cells were shown to be polyclonal in origin by their heterogeneous TCR $V_{\beta}$ repertoire. Similar observations were made previously in $A b^{0} / A b^{0}$ class II knock-out mice $(8,9)$. We can now exclude that these cells had matured by interaction of their TCR with $A \alpha E \beta$ heterodimers of mixed isotypes, since these heterodimers are absent in our $A a^{0} / A a^{0}$ class II mutant mice. They may, however, be restricted to the novel MHC class II H-20 molecules. Alternatively, the remaining $\mathrm{CD} 4{ }^{+} \mathrm{CD} 8-$ cells may represent cells that have not been positively selected at all, but were able to escape programmed cell death. The other possibility-mentioned already above for the development of $\mathrm{CD4}{ }^{+} \mathrm{CD} 8^{\text {low }}$ thymocytes - is that $\mathrm{CD4}{ }^{+} \mathrm{CD} 8-\mathrm{T}$ cells from the mutant are in fact $\mathrm{MHC}$ class I restricted and have retained an inappropriate coreceptor molecule because the affinity of the TCR alone determined the pathway of differentiation. These cells would be expected to perform cytotoxic rather than helper functions despite their CD4 expression. Indeed, T cell help for $\mathrm{lg}$ class switch was absent in MHC class II deficient mice after challenge with a $T$ cell dependent antigen (9). B cells from mutant are functional, however, as shown by their normal responses to the $T$ cell independent antigen levan.

We have observed a 2-fold reduction of Pgp-1 thoth $^{\text {expressing }}$ thymocytes in the mutant. Such cells are found mainly in the medulla of the thymus (26). Thus it appears that development of Pgp- $1^{\text {high }}$ expressing thymocytes may be controlled by interaction with $\mathrm{MHC}$ class II molecules.

$\mathrm{MHC}$ class II deficient $\mathrm{B6}-\mathrm{A} \mathrm{a}^{\circ} / \mathrm{A} \mathrm{a}^{0}$ mice provide a useful tool to study the central role of MHC class II molecules in autoimmune diseases, allergies, and allograft reactions.

In addition, reconstitution experiments of $B 6-A a^{\circ} / A a^{\circ}$ mice with different $M H C$ class II expressing isogenic cells may reveal their involvement as antigen presenting cells in immune responses. 


\section{Acknowledgements}

We gratefully acknowledge Yolande Lang for the generation of $\mathrm{B6}-\mathrm{Aa} / \mathrm{Aa} \mathrm{a}^{0}$ mice by microinjection of mutant ES cells into blastocysts and Pascale Koebet for assistance in the analysis of these mice. We appreciate the help of Dr Lucia Mori, who made antibodies specific for some TCR $V_{\beta}$ regions available to us. We thank Dr Chris Gray for suggesting to test MHC class II expression with SEB, and Drs Joachim Rothe and Debbie Hartman for critically reading the manuscript.

\section{Abbreviatlons}

$\operatorname{Con} A$

ES cells

HSA

LPS

PCR

concanavalin A embryonic stem cells heat stable antigen lipopolysaccharide polymerase chain reaction

\section{References}

1 Kisielow, P., Teh, H. S., Bluethmann, H., and von Boehmer, H. 1988. Positive selection of antigen-specific $T$ celts in thymus by restricting MHC molecules. Nature 335:730.

2 Teh, H. S. Kiseilow, P., Scott, B., Kishi, H., Uematsu, $Y$., Bluethmann, $H$., and von Boehmer, $H .1988$. Thymic major histocompatibility complex antigens and the $\alpha \beta T$ cell receptor determine the CD4/CD8 phenotype of $T$ cells. Nature 335:229

3 Sha, W. C., Nelson, C. A., Newberry, R. D., Kranz, D. M., Russell, J. H., and Loh, D. Y. 1988. Positive and negative selection of an antigen receptor on T cells in transgenic mice. Nature $\$ 36: 73$.

4 Berg, L. J., Pullen, A. M., Fazekas de St Groth, B., Mathis, D., Benoist, C., and Davis, M. M. 1989. Antigen/MHC-specific T cells are preferentially exported from the thymus in the presence of their MHC ligand. Cell 58:1035.

5 Kaye, J., Hsu, M. L., Sauron, M. E., Jameson, S. C., Gascoigne, N. R. J., and Hedrick, S. M. 1989. Selective development of CD4 ${ }^{+} T$ cells in transgenic mice expressing a class II MHC-restricted receptor. Nature 341:746.

6 Zijtstra, M., Li, E., Sajjadi, F., Subramani, S., and Jaenisch, R. 1989. Germ-line transmission of a disrupted $\beta_{2}$-microglobulin gene produced by homologous recombination in embryonic stem cells. Nature 342:435.

7 Koller, B. H., Marrack, P., Kappler, J. W., and Smithies, O. 1990. Normal development of mice deficient in $\beta_{2} M_{1}$ MHC class I proteins, and $\mathrm{CD}^{+}{ }^{+} \mathrm{T}$ cells. Science 248:1227.

8 Cosgrove, D., Gray, D., Dierich, A., Kaufman, J., LeMeur, M., Benoist, C., and Mathis, D. 1991. Mice lacking MHC ckass II molecules. Cell 66:1051.

9 Grusby, M. J., Johnson, R. S., Papaioannou, V. E., and Glimether, L. H. 1991. Depletion of $C D 4+T$ celts in major histcompatibility complex class II-deficient mice. Science 253:1417.

10 Mathis, D. J., Benoist, C. Williams, V. E., Kanter, M. and McDevitt, H. O. 1983. Several mechanisms can account for defective E $\alpha$ gene expression in different mouse haplotypes. Proc. Natt Acad. Sci. USA 86:273.

11 Ledermann, B. and Bürkj, K. 1991. Establishment of a germ-line competent C57BL/6 embryonic stern cell tine. Exp. Cell. Res. 197:254.

12 Thomas, K. R. and Capecchi, M. R. 1987. Site-directed mutagenesis by gene targeting in mouse embryo-derived stem celts. Cell 51:503.

13 Adra, C. N., Boer, P. H., and McBurney, M. W. 1987. Cloning and expression of the mouse $\rho g k-1$ gene and the nucleotide sequence of its promoter. Gene 60:65

14 Abbondanzo, S. J., Gadi, I., and Stewart, C. 1993. Derivation of embryonic stem cell lines. Methods Enzymot., in press.

15 Stewart, C., Schuetze, S., Vanek, M., and Wagner, E. 1987. Expression of retroviral vectors in transgenic mice obtained by embryo infection. EMBO J. 6:383.

16 Kontgen, F. and Stewart, C. 1993. A simple screening procedure to detect gene targeting events in embryonic stem cells. Methods Enzymol. in press.

17 Stewart, C. L. 1993. Production of chimeras between embryonic stem cells and embryos. Methods Enzymot. in press.

18 Chalot, C. L., Zromek, C. A., Bavister, B. D., Lewis, J. L., and Torres, I. 1989. An improved culture medium supports devedopment of rendombred 1-cell mouse embryos in vitro. J. Reprod. Fert. 86:679.

19. Bluethmann, $H$. and Steinmetz, M. 1990. Transgenic mice for analysis of $T$ cell development. In Lefkovits, I. and Pernis, B. eds, Immunological Methods, vol. IV. p. 311. Academic Press, Ortando.

20 Gregoire, C., Rebai, N., Schweisguth, F., Necker, A., Mazza, G. Auphan, N., Millward, A., Schmitt-Verhulst, A. M., and Malissen, B. 1991. Engineered secreted T-cell receptor $\alpha \beta$ heterodimers. Proc. Natl Acad. Sci. USA 88:8077.

21 Pullen, A. M., Marrack, P., and Kappler, J. W. 1988. The T ceil repertoire is heavily influenced by tolerance to polymorphic self antigens. Nature 335:796.

22 Payne, J., Huber, T. H. Cannon, N. A. Schneider, R., Schilam, M. W., Acha-Orbea, H., MacDonald, H. R., and Hengartner, H. 1988. Two monoclonal rat antibodies with specificity for the $\beta$-chain variable region of the murine T-cell receptor. Proc. Natt Aced. Sci. 85:7695.

23 Staerz, U., Rammensee, H., Benedetto, J., and Bevan, M. 1985. Characterization of a murine monoclonal antibody specific for an allotypic determinant on T cell antigen receptor. J. Immunol. 134:3994.

24 Bill, J., Kanagawa, O., Woodland, D. L., and Palmer, E. 1989. The $M H C$ molecule $I-E$ is necessary but not sufficient for the clonal deletion of V 11 -bearing T cells. J. Exp. Med. 169:1405.

25 Kappter, J. W., Wade, T., White, J., Kushnir, E., Blackmąn, M., Bit, J., Roehm, N., Marrack, P. 1987. A T-cell receptor VB segment that imparts reactivity to a class II Major. Histocompatibility Complex. product. Cell 49:263.

26 Haynes, B. F., Telen, M. J., Hale, L. P., and Denning, S. M. 1999. CD44.A molecule involved in leukocyte adherence and $T$ cell activa. tion. Immunol. Today 10:423.

27 Ruberti, G., Sellins, K. S., Hill, C. M., Germain, R. N., Fathman, C. G., and Livingstone, A. 1992. Presentation of antigen mixed isotype class II molecules in normal $\mathrm{H}-2^{d}$ mice. J. Exp. Med. 175:157.

28 Kimoto, M., Seki, K., Matsunage, M., and Mineta., T. 1989. Unique mixed tymphocyte-stimulating determinants in $E_{d}$ alpha geneintroduced C57BL6 transgenic mice. Immunology 67:154.

29 Anderson, G. D. and David, C. S. 1989. In vitro expression and function of hybrid la dimers ( $E \alpha A \beta$ ) in recombinant and transgenic mice. J. Exp. Med. 170:1003.

30 Anderson, G. D., Banerjee, S., and David, C. S. 1989. MHC class II

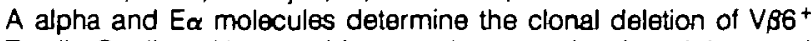
$T$ cells. Studies with recombinant and transgenic mice. J. Immunol. 143:3757.

31 Matsunaga, M., Seki, K., Mineta, T., and Kimoto, M. 1990. Antigenreactive $T$ cell clones restricted by mixed isotype $A \beta^{d} / E \alpha^{d}$ cless II molecules. J. Exp. Med. 171:577.

32 Takahama, Y. and Singer, A. 1992. Post-transcriptional regulation of early T cell devetopment by T cell receptor signals. Science 258:1456.

33 Zuniga-Pflucker, J. C., Longo, D. L., and Kruisbeek, A. M. 1989. Positive selection of CD4-CD8 ${ }^{+}$T cells in the thymus of normal mice. Nature 338:76.

34 Nakayama, T., June, C. H., Munit, T. I., Sheard, M., McCarthy, S. A., Sharrow, S. O., Samelson, L. E., and Singer, A. 1990. Inhibition of $\mathrm{T}$ cell receptor expression and function in immature $\mathrm{CD} 4{ }^{+} \mathrm{CD} 8{ }^{+}$ cells by CD4. Science 249:1558.

35 Guidos, C. J., Danska, J. S. Fathman, G., and Weissman, I. L. 1990 $T$ cell receptor-mediated negative selection of autoreactive $T$ lymphocyte precursors occurs after commitment to the $\mathrm{CD} 4$ or $\mathrm{CD} 8$ lineages. J. Exp. Med. 172:835

36 Shortman, K., Vremec, D., and Egerton, M., 1991. The kinetics of $T$ cell antigen receptor expression by subgroups of $\mathrm{CD}^{+} 8^{+}$ thymocytes: delineation of $\mathrm{CD}^{+} 8^{+} 3^{(2+)}$ thymocytes as postselection intermediates leading to mature T cells. J Exp Med 173:323.

37 Kartsson, L., Surh, C. D., Sprent, J., and Peterson, P. A. 1991. A novet class II MHC molecule with unusual tissue distribution. Nature 351:485. 